Journal of Economics and Behavioral Studies

Vol. 4, No. 5, pp. 287-296, May 2012 (ISSN: 2220-6140)

\title{
Determinant Attributes of Customer Choice of Banks, Supplying Mortgage Products
}

\author{
*Irfan Ahmed ${ }^{1}$, Saira Ashfaq ${ }^{1}$, Shahid Mahmood ${ }^{1}$, Umar Farooq ${ }^{2}$ \\ ${ }^{1}$ University of Sargodha, Sargodha, Pakistan \\ ${ }^{2}$ Riphah International University, Islamabad, Pakistan \\ *irfan.6007@yahoo.com
}

\begin{abstract}
The present study focuses on finding out the main attributes that determine the customer's choice of bank for supplying the mortgage products. The data has been gathered through questionnaires from 400 customers using mortgage products of different banks. Reviewing the literature four variable are taken for study to determine the dependent variable customer choice of banks using mortgage products and they include cost of bank, quality of services, confidence of customer in bank and convenience of customer using mortgage product. Results were analyzed using ordinary least square (OLS) regression and correlation techniques and findings of the data have been tested which appeared as significant statistically. The results indicated that choice of customers for the mortgage product depends on all the independent variables like quality of services, cost of mortgage product, confidence level of customers build by the bank and convenience of the customers. Further analysis can be done on exploring more independent variables, which are important for customers in choosing a bank providing mortgage products.
\end{abstract}

Keywords: Selection of Mortgage provider, Mortgage products, Determinant attributes, OLS Regression

\section{Introduction}

The most common definition of the mortgage is a loan to finance the purchase of real estate, generally with specified interest rate payment period. The borrower (mortgagor) gives the lender (mortgagee) a lien (form of security) on the property as collateral (borrower's pledge of specific property to a lender, to secure repayment) for the loan. Mortgage provider is the lender like bank. According to the literature, key factors, which have significant impact on the selection of the bank, are low interest rate on loan, quality of services, location, reputation, high interest rate on saving and safety. Financial organization assortment criteria significance changes among diverse geographical areas, and demographic distinctiveness of the population and so research on bank decision making should comprise a variety of demographic and geographical segments where important customers are present (Boyd et al. 1994). Most important factors, which have a considerable impact on the selection of the mortgage provider, are services speed; friendly environment and accuracy in account transaction management but price, location of mortgage provider and convenience have no less impact on the selection of mortgage provider (Zineldin, 1996). Some bank selection determinants vary from one segment to another of the market and it should be in knowledge of bank management (Edris, 1997). Some more important key factors, which affect the selection of the bank, are availability of credit, recommendation, account charges, staff friendliness and reputation. Some unimportant factors having lesser impact on the choice of the bank are interest on saving account, new account premium and hours of operation (Anderson, Cox \& Fulcher, 1976). Acquiring of the mortgage products is a very risky task so it is required a high involvement for the purchase decision making (Aldlagain \& Buttle, 2001). Important factors which affect the customer's choice are staff friendliness, speediness of the process, reputation of banks, services quality and cost of loan but the unimportant factors include financial advice availability, effective advertisement of the bank and availability of direct deposit (Khazeh \& Decker, 1992). Availability of ATM, speed of processes and loyalty with customers are the major factors, which are affecting the choice of mortgage providers (Ulengin, 1998). Involvement varies from customer to customer, product-having importance for one may not be equally important for the other customer. Preferable characteristics of mortgage product also vary. Customers compare the total features of the mortgage product of one provider with the other (Talaga \& Buch, 1998). 
Quality of the services, convenient in terms of location, benefits on deposits like high interest rate, low cost of loan and self-banking are the important factors and have the significant influence in the selection of the bank. On the other hand, long timings, special packages of the students and recommendation have no significant effect on the choice of the customers (Ta \& Har, 2000). Professional advice, interest rate, lending amount, relationship with the customers and loyalty are the most important factors and effects the customer's choice but the quality of services and reputation of the mortgage provider have very little effect on the choice of the customers. Location of the mortgage provides has no effect on the selection or the choice of the customer (Devlin, 2002). There is a substantial amount of research conducted on selection of mortgage provider in developed countries. In developing countries, very less concentration has been given to this research area. Some researchers studied this relationship before but findings are not sufficient to determine the actual factors that actually affect the choice of customers for the selection of mortgage providers. Cost of the mortgage is one of most important determinant attribute of customer's choice of bank because Pakistan is a developing country so Pakistani's are very sensitive in the matter of cost but it is a factor of great importance all around the world. Services' quality of the bank also affects the choice of the customers. Confidence and convenience have also impact on the selection of the mortgage provider but it is not much significant like cost of the mortgage product and services quality of banks. Pakistan is a developing country and baking sector of Pakistan has significant importance because majority of the people in Pakistan depend on the loans for the investments and even though for the necessary needs. After studying literature on these variables it is found that existing research on factors determining attribute of customer's choice of bank are not enough to explore the actual determinants. This research will try to find out exact determinants affecting customer's choice of bank using mortgage products in context of Pakistan. After the review of the studies done in other countries, we are intending to do the study in Pakistan's perspective that what are the behavioral factors that affect the choice of mortgage providers in developing economies like Pakistan.

\section{Literature Review}

In the present study, there are one dependent variable "choice of mortgage provider" and four independent variables including cost of mortgage providers, convenience, and services quality of banks and confidence level of customers.

Selection of Bank: Bank customers put a deep emphasis on helpful staff attitude, well-informed staff, sociability of bank workers, employee professionalism, politeness of staff, and appropriate employee responses to correspondence. Foreign banks are preferable because of banks performance but the Chinese banks are preferable because of convenient network (Heijes, 2008). There is a great impact on the choice of the customers is the loan performance (Yang et al, 1998). Market power effect the performance of the individual bank having very little impact. First, mortgage brokers get fees for creation of mortgages, not for scheming mortgage risks. Second, mortgage lender's earnings augment as they make mortgage group and securitize the funding of those pools. It seems that the lenders looked mostly to these earnings, without much deliberation of the greater failure to pay losses that would later attend riskier loans. Third, if lending principles are changing then failure to pay rates are likely to be changing commensurately, but it is questionable whether the software programs were modified to reproduce the increased risks (Johnson and Neave, 2008). Modify the home employment distinctiveness and the impending for the appearance of both favorable and unfavorable financial situation will have to acclimatize by the mortgage designers (Leece, 1997). Choice of the mortgage provider depends on the perception of the customers about that bank. It may be created by the experience with that bank so it is depending on the customer relationship (Roos, Gustafsson and Edvardsson, 2006). Risk of the mortgage can be reduced by lowering the advantage requirements (Calem \& Follain, 2007). For success in the mortgage regulations, change is necessary in the services standards (Cummings, 2008). Lenders and mortgage investors busy in these products will be capable to securitize their privileges to equity appreciation, buy, and sell the advantage of home price appreciation prepared doable by such a product (Sharma, 2010). Position of the banks and its product effect the decision of the customers. Some position is based on the quality, comfort and some base on the price. Convenience of the location of bank is not the major determinant of the selection of the customers for a bank (Zineldin, 2005). There are important factors, which are effecting the decision of the customers for the selection of the mortgage providers are friendliness and helpfulness of personnel, accuracy in account transaction management, efficiency in correcting mistakes, and speed of service and decision (Zineldin, 1996). 
Cost of mortgage: Seller-paid discount points can get more capitalization profit than the seller paid closing cost so seller-paid closing costs do not bestow the same capitalization profit as seller-paid markdown points. A discount point concession is better than the closing cost concessions because closing cost concessions is simply increasing the out of pocket expenses of the mortgage product (Asabere and Hoffman, 1997). There are the numbers of advantages for the both low-income households and public policy usually by the accessibility of relatively low cost mortgage credit from the local government sector. These loans enlarge opportunities for credit and homeownership and makes sure that the marketplace is entire with the most profit accumulated to those who are not capable to use the services of conventional lenders (Coates, 2008). When conventional mortgages are, involved home sellers are capable to get better their point concessions in the shape of price premiums; sellers materialize to be controlled in their ability to take out such considerable premiums when it comes to governmental insured or guaranteed loans (Asabere and Hoffman, 1997). Low income homebuyers and in do so can access the mortgage finance by the offering the local government at low cost. There is essentially a trade-off between growing occasions for entrance credit at a reasonable cost against a risk of non-payment of this debt (Coates, 2008). Borrowers main focus is the on the size of the payments (Scanlon, Lunde and Whitehead, 2008). Customers prefer or desire the mortgage, which has no additional fees (Talaga and Buch, 1998). Mortgagors hold a prepayment option and it has the direct effect on the decision of the customers (Charlier and Bussel, 2003).

Risk-averse people prefer the fixed rate of the mortgage but the risk seeking prefer the adjustable rate of the mortgage (Mori, Ziobrowski and Rottke, 2010). Price of the mortgage can be determined by value of service to particular customer segments, and the flexibility of demand of chosen target market, may play a more important role in order to improve customer devotion and augment the usage of selected mortgage products (Meidan and Chin, 1995). Price is not only the main focus of the banks but higher prices can be justified with the higher product quality (Zineldin, 2005). Competition that is more efficient can be generated by the low transaction cost (Schuck, 1994). Mortgage charges of banks have no much effect from the concentration and loan price ratio. However, the charges can be affected by the numbers of the banks and the users of the banks in the market (Hung, 1999). Return on loans, return on equity and real estate loans to total loans ratios may considerably affected by Prepayment risk of various commercial banks (Fayman and He, 2011). Mortgage fees depend on the service area size each bank has in a given market and the market size or population is likely to have a negative impact on these charges. Interest rate is an important determinant of the loan-price ratio. Concentration and loan price ratio have no considerable effect on the mortgage charges. Charges can be affected by the number of banks in the market (Hung, 1999). Interest charged on loans and interests on savings accounts are the important determinants of the customer's choice of a bank. Friendliness of employees, modern facilities, and drive-in service are the less important factors (Boyd, Leonard and White, 1994). Price and the cost is the most important factor for the selection of the banks because it is a financial services industry and customers choice mostly depend on the cost related factors (Zineldin, 2005).

$\mathrm{H} 1$ : Cost of the mortgage negatively associated with the choice of the mortgage provider

Confidence of customers: There are five valid criteria for the selection of the banks and one of them is reputation of the banks. Word of mouth is very much important for the development of the reputation of bank (Zineldin, 2005). The determinants of the customer's choice are bank assets, help in financial emergencies, bank experience, reputation, knowledge about the firm's activities (Edris, 1997). Experience is very much important for the selection of the bank and it comes from the interaction with the supplier of services (Loughlin, Szmigin and Turnbull, 2004). An important criterion for the selection of the bank is reputation of the bank (Boyd, Leonard and White, 1994). There are five majors dimensions by which customers evaluate the banks are service quality, credit availability and price competition, delivery system, promotion, reputation and differentiation (Zineldin, 1996).

H2: There is a positive relationship between the confidence of customers and choice of the mortgage provider

Services quality: There are five main attributes to determine the customer's behavior to select the banks are service quality, credit availability, price competition, delivery system, promotion, reputation and differentiation. According to customer's point of view, account and transaction accuracy carefulness, efficiency in correcting mistakes, friendliness and helping behavior of personnel clearly appear as the most important determinants of bank selection (Zineldin, 2005). These determinants engage efficiency of staff, friendliness of staff, communication with staff, prompt provision of services, and availability of branches 
abroad. Services of the bank information and the competitive advantage effect the decision of the customers for the selection of the bank (Ta and Har, 2000). There are the four main factors, which affect the customer's bank choice decision. These are bank services quality, product attributes, access and communication. Bank services quality is a most important factor. Services qualities, bank reputation, customer's perception about bank are the most important factors, which are affecting the customer's choice of a bank for the mortgage loan. A key to gain the competitive advantage is the services quality. By providing the high services, quality banks can create a long-term good relationship with customers (Lymperopoulos, Chaniotakis, Soureli, 2006). Services quality has a significant effect on the choice of the customers (Patricio, Fisk and Cunha, 2003). By eliminating the paper work from the procedures of the bank than it will lead to improve the services quality. Services are the major determinant but the convenience of the location is less important determinant (Zineldin, 1996).

H3: Services quality is positively associated with the selection of mortgage provider

Convenience: Behavior of bank employees, bank service charges, and extra services offered by the bank, confidence in the bank, positive bank image and convenience are the important determinants for the selection of the customers of a bank. Professional advice and interest rate also effect the choice decision of the customers (Devlin 2002). Customers bank choice determinants are size of bank assets, location, banking experience, availability of branches abroad, lending policy, and reputation, range of services, innovation, and interests on deposits. Customer's choice depends on the design of mortgage loan, repayments terms, customer's satisfaction, services charges and interest rate. Communication with customers and the ease for them also affect their decision (Lymperopoulos, Chaniotakis, Soureli, 2006). Low cost and convenience are preferable for the customers. If customers are satisfied then they will prefer the bank. Interaction plays an important role for creating the loyalty with the customers and when they are loyal then they will prefer that bank (Farquhar, Len and Wright, 2008). Convenience and customer's satisfaction are the main determinants of the customer's selection of bank (Moutinho and Smith, 2000).

H4: There is a positive relationship between the convenience of customers and the selection of the mortgage providers

Figure 1: Theoretical framework of research paper

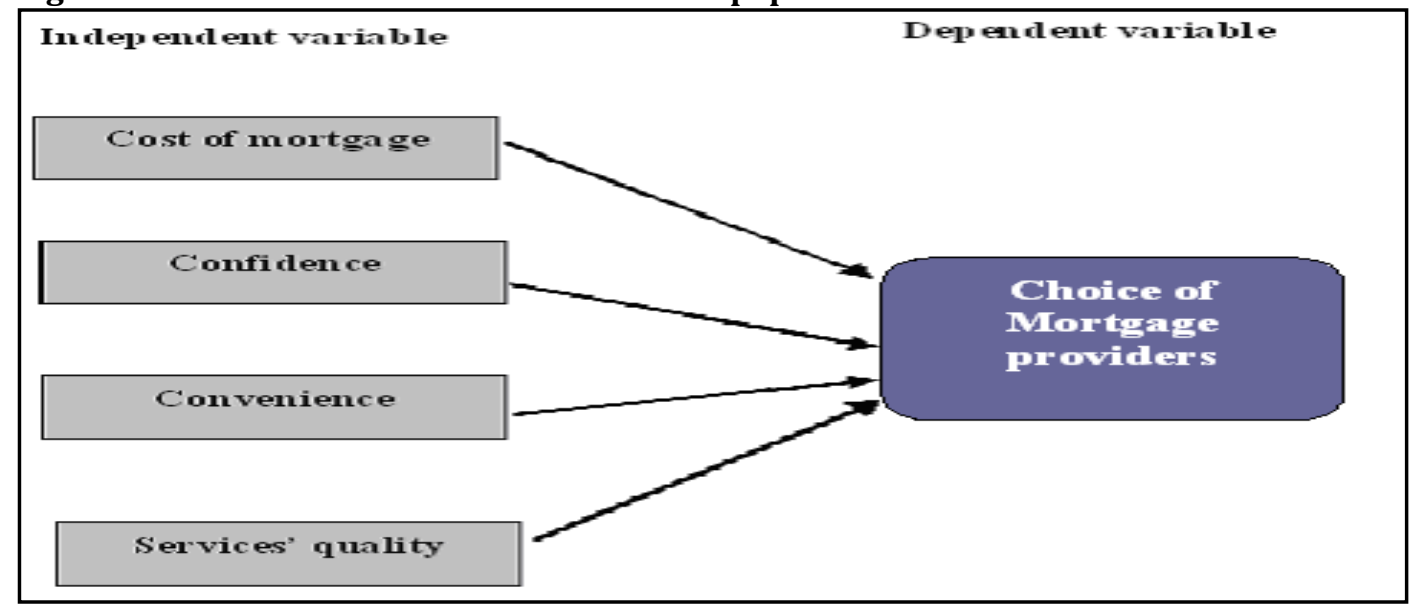

Figure 1: Cost mortgage product

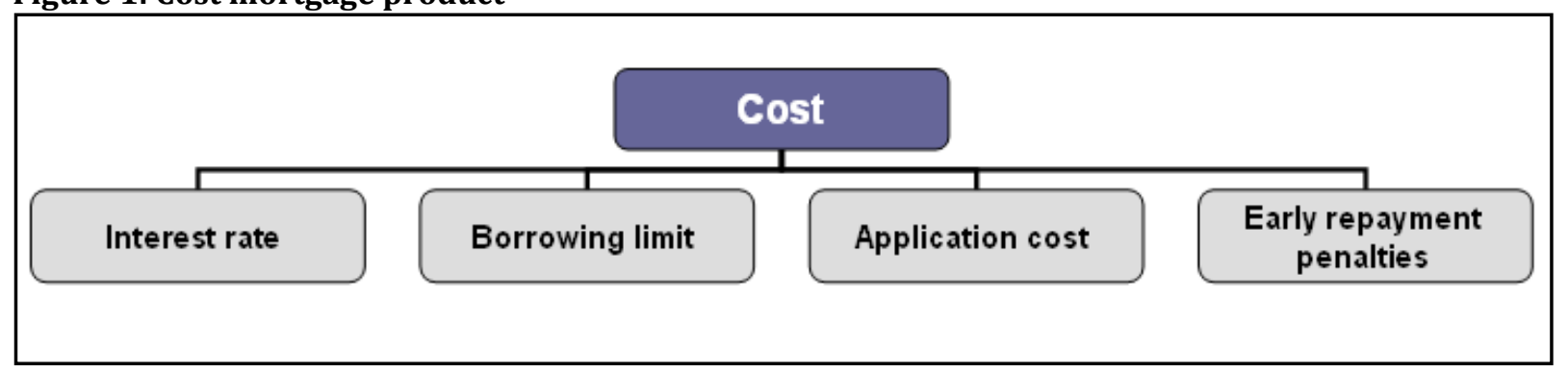




\section{Theoretical framework}

Description of model: Theoretical framework shows the model of the research. In this particular study, there is only one dependent variable and four independent variables. Selection of the mortgage providers depend on the cost of mortgage product, services quality, convenience for customers and confidence level of customers.

\section{Dependent variable}

Choice of Mortgage provider: It is the dependent variable, which can be affected by the independent variables like cost of mortgage, confidence level, convenience and quality of the services.

\section{Independent variables}

Cost of the mortgage: It is the independent variable, which includes the interest rate, borrowing limit, application cost and early repayment penalties.

Convenience: Convenience level is also an independent variable, which can be affecting to the choice of the mortgage provider. It includes the liberal approval, ease and convenience of contact and bundle with other product.

Figure 2: Convenience of customers

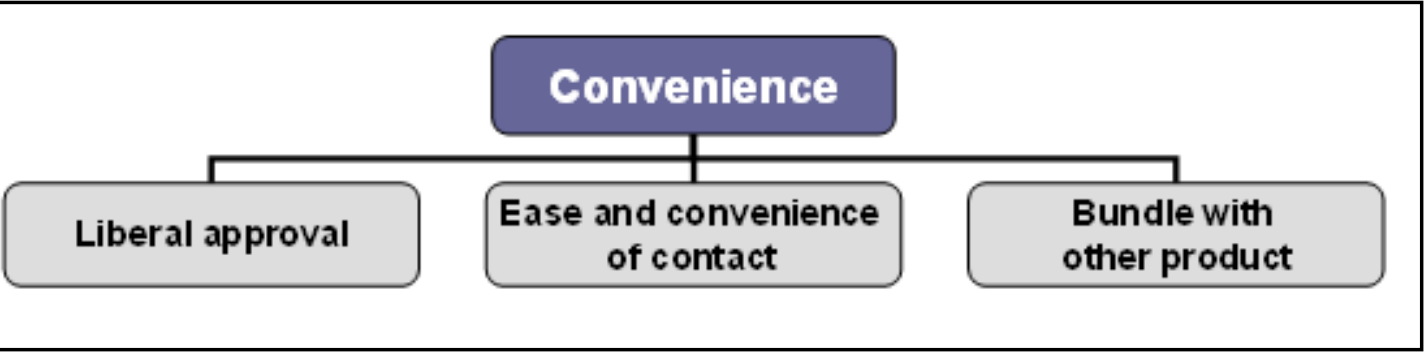

Figure 3: Confidence level of customers

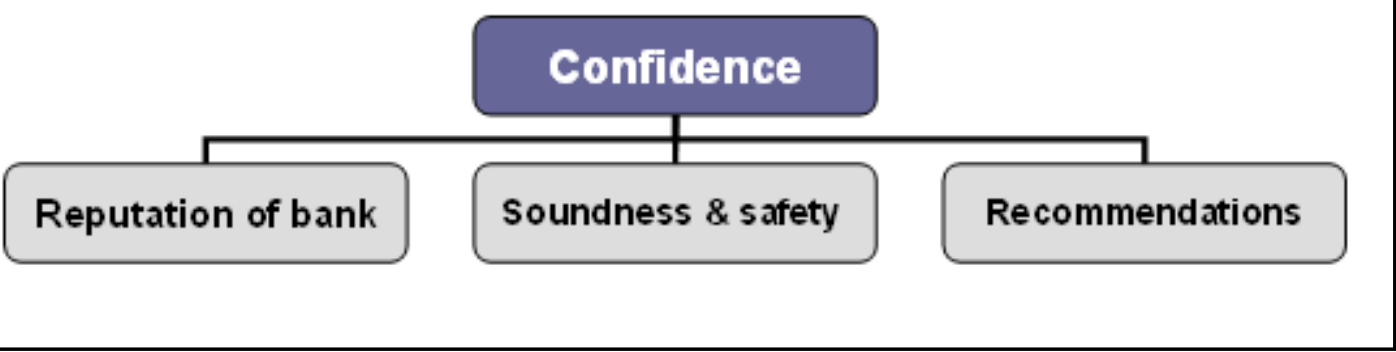

Figure 4: Services' quality of banks

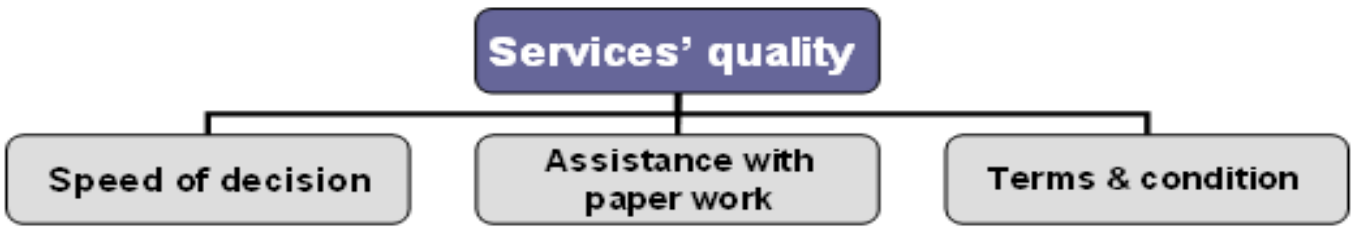


Confidence: Confidence of the customers is also an-other independent variable. It includes the reputation of the mortgage provider or bank, soundness and safety of the bank and recommendations.

Services' quality: Services' quality is also independent variable, which may be having a significant impact on the selection of mortgage, provide. It consists on the speed of decision, assistance with paper work and terms and condition of mortgage.

\section{Methodology}

Questionnaire was adopted form Kotykhov (2005). It contained 30 (thirty) items and 3 (three) sections. Section one has 3 (three) items which are related to association of the customers with bank i.e. currently using the product of which bank and how many visits he made for the concern product. Section two has 21 (twenty-one) items which are the research model relevant questions and section three contains 6 (six) questions related to demographic (of respondents). The population for data collection was customers using the mortgage product of Pakistan. The sample was collected from three cities of Pakistan i.e. Sargodha, Lahore and Rawalpindi and the sample size was 400 customers randomly selected from the three cities. The questionnaire was personally administered through customers. Total 400 (four hundred) questionnaires were distributed out of 305 (three hundred and five) questionnaires were received back which gives a good response rate of $76 \%$. Data was collected from both males and females for the avoidance of the biased results. So the characteristic i.e. gender, Age, Duration with bank, Visits of banks, Occupation, Experience, Qualification and income of the customers vary from customer to customer so all above Characteristics of the respondents of sample are summarized in the following table.

Characteristics of sample: In the society of Pakistan, females are less empower then man for the decisionmakings i.e. for the selection of mortgage, males decisions are more preferable then female. In this country, mostly females are homemakers and they have no concern with the businesses and any other activities so they have no need to take the loans from banks. That is why the ratios of the female respondents are very much less then male respondents in the sample size. Only $21 \%$ response was gathered from the females, they got the mortgage loan for the marriages of their daughters and some of them took the loan for the business purpose but they are very less in amount.

\section{Results}

Statistical Package for the Social Sciences (SPSS) is used for the results. Correlation analysis shows the relationship among the variables and the regression analysis shows the confidence level, significance and beta. Regression analysis also shows the model summary.

Correlation: Linear association is checked by the Pearson correlation analysis between the variables in the study. Correlation statistics shows the association between the variables that how the two variables are associated with each other, it tells that if one variable moves in one direction the other variable will move in the similar direction or opposite to that. We found that the dependant variable selection of the bank is having highly significant and positive association with all the four independent variables. The association between the independent variables shows that they are strongly associated between themselves and all of the correlation results are significant at the level of $1 \%$. Collinearity statistics shows that there is a chance of multicollinearity in the data but variance inflation factor (VIF) which is the test for checking multicollinearity shows that there is no such problem of multicollinearity as all the values of VIF are less than 10 and tolerance values are below 1.

Regression: Regression test is used to check the relationship between the dependent and independent variables. Regression results show the significance of the regression model and its explanatory power. The regression analysis indicates that the value of $\mathrm{R}$ Square is 0.747 , which indicates that there is $74.7 \%$ variation in selection of banks is explained by the variables in the study while $25.3 \%$ variation is due to those factors, which are not considered in this model. The value of $\mathrm{F}$ is 148.953 and is significant showing the fitness of the model. The results of the study showed that all the variables have significant impact on the selection of bank. 
Confidence is having strong positive relationship with selection of mortgage provider. Result suggests that 1 unit increase in confidence will increase the chances of bank selection by 0.363 . Cost is also having significant impact on the selection of bank but results are significant at the level of 5\%. Services quality has positive and strong relationship with the customer's choice of bank. Regression result shows that 1 unit increase in service quality will result an increase of 0.272 in the selection of bank and the result is significant at the level of $1 \%$. Convenience has a strong positive significant relationship with the choice of bank, which is providing the mortgage products.

Table 1: Characteristics of sample

\begin{tabular}{|c|c|c|c|c|}
\hline $\mathrm{S} / \mathrm{N}$ & Items & Items & Frequency & Percentage of frequency \\
\hline \multirow[b]{2}{*}{1} & \multirow[b]{2}{*}{ Gender } & Female & 66 & $21 \%$ \\
\hline & & Male & 239 & $79 \%$ \\
\hline \multirow{6}{*}{2} & \multirow{6}{*}{ Age } & $21 \&$ less & 2 & $0.7 \%$ \\
\hline & & $21-25$ & 0 & $0 \%$ \\
\hline & & $26-30$ & 20 & $6 \%$ \\
\hline & & $31-35$ & 46 & $16 \%$ \\
\hline & & $36-40$ & 49 & $16 \%$ \\
\hline & & $41-45$ & 55 & $18 \%$ \\
\hline & & $46-50$ & 74 & $24 \%$ \\
\hline \multirow{6}{*}{3} & \multirow{7}{*}{$\begin{array}{l}\text { Duration with } \\
\text { bank }\end{array}$} & $51 \&$ above & 59 & $19 \%$ \\
\hline & & Less than 1 year & 0 & $0 \%$ \\
\hline & & $1-3$ years & 65 & $21 \%$ \\
\hline & & 3-5 years & 73 & $24 \%$ \\
\hline & & 5-7 years & 78 & $26 \%$ \\
\hline & & More than 7years & 89 & $29 \%$ \\
\hline & & Less than 5 times & 5 & $2 \%$ \\
\hline \multirow[t]{6}{*}{4} & \multirow[t]{6}{*}{ Visits of banks } & 5-7 times & 63 & $21 \%$ \\
\hline & & 7-9 times & 74 & $24 \%$ \\
\hline & & 9-11 times & 78 & $26 \%$ \\
\hline & & More than 11 & 85 & $28 \%$ \\
\hline & & Students & 2 & $0.7 \%$ \\
\hline & & Business sector & 89 & $29 \%$ \\
\hline \multirow[t]{5}{*}{5} & \multirow[t]{5}{*}{ Occupation } & Land lords & 78 & $26 \%$ \\
\hline & & Job holders & 27 & $9 \%$ \\
\hline & & Manufacturer & 85 & $28 \%$ \\
\hline & & Education sector & 24 & $8 \%$ \\
\hline & & Significant & 76 & $25 \%$ \\
\hline \multirow[t]{3}{*}{6} & \multirow[t]{3}{*}{ Experience } & Little & 209 & $69 \%$ \\
\hline & & No & 20 & $7 \%$ \\
\hline & & Less than 25000 & 5 & $2 \%$ \\
\hline \multirow[t]{4}{*}{7} & \multirow[t]{4}{*}{ Income } & $25001-35000$ & 24 & $8 \%$ \\
\hline & & $35001-50,000$ & 63 & $21 \%$ \\
\hline & & Above 50,000 & 213 & $69 \%$ \\
\hline & & Inter & 105 & $34 \%$ \\
\hline \multirow[t]{3}{*}{8} & \multirow[t]{3}{*}{ Qualification } & Undergraduate & 96 & $31 \%$ \\
\hline & & Graduate & 70 & $23 \%$ \\
\hline & & Post graduate & 36 & $12 \%$ \\
\hline
\end{tabular}


Table 2: Correlation among variables

\begin{tabular}{lccccc}
\hline & Bank selection & Confidence & Cost & Services & Convenience \\
\hline Bank selection & 1 & $0.806^{* *}$ & $0.769^{* *}$ & $0.757^{* *}$ & $0.759^{* *}$ \\
Confidence & $0.806^{* *}$ & 1 & $0.784^{* *}$ & $0.716^{* *}$ & $0.746^{* *}$ \\
Cost & $0.769^{* *}$ & $0.784^{* *}$ & 1 & $0.759^{* *}$ & $0.737^{* *}$ \\
Services & $0.757^{* *}$ & $0.716^{* *}$ & $0.759^{* *}$ & 1 & $0.700^{* *}$ \\
Convenience & $0.759^{* *}$ & $0.746^{* *}$ & $0.737^{* *}$ & $0.700^{* *}$ & 1 \\
\hline
\end{tabular}

Table 3: Regression analysis

\begin{tabular}{llll}
\hline & Beta & t & Significant \\
\hline Confidence & .363 & 5.637 & .000 \\
Cost & .140 & 2.252 & .025 \\
Services & .272 & 4.030 & .000 \\
Convenience & .208 & 3.706 & .000 \\
\hline
\end{tabular}

$\mathrm{N}=305$

Dependent variable $=$ Selection of bank

R square $=0.747$

Adjusted R square $=0.742$

$F=148.953$, Significance $=.000$

\section{Model summary}

Table 4: Model summary

\begin{tabular}{lllll}
\hline Model & R & R Square & Adjusted R Square & Std. Error of the Estimate \\
\hline 1 & $0.864^{\mathrm{a}}$ & 0.747 & 0.742 & 0.42689 \\
\hline
\end{tabular}

\section{Conclusion}

Selecting a bank is an important decision in developing countries where economic situation is not stable. 400 questionnaires were distributed among customers of banks. In all, 305 usable surveys were returned which represented the relationship between all variables. The result of this particular study indicates that the people of developing countries prefer those institutions in which they are having more confidence. In confidence, customers are only conscious about the reputation of the bank to avoid the frauds and like to take the mortgage products from the safe banks. As Pakistan is, a developing country so people are money oriented. They like to avail the low cost products. They want to take the financial products from those banks, which are charging them low interest rates and others charges also. After the literature review, it was hypothesized that cost is negatively associated with the selection of the bank but results are not in accordance with the expectations. The people will prefer the bank where quality of the service is better as compared to competitors. Some customers like assistance during the paper work but some do not like. They feel a pressure on them. Mostly experienced customers do not like assistance with them because they have much knowledge about the documents of the banks so they feel uncomfortable with the assistance. However, the customers who have no much experience like assistance with them for paper work. Therefore, there is positive relationship exists between these two variables. Convenience in the modern era has become important factor as well and shows that it effects the choice of bank significantly and it may be depending on the location of the banks as well the ease of understanding the terms and conditions of mortgage loans.

Limitations and Recommendations: There are two limitation of this study. One is that data is collected only from the Punjab province and the remaining three provinces are neglected i.e. Sindh, Balochistan and Khyber Pakhtunkhaw. Second limitation is that the research paper based only on the conventional banks and the Islamic banks are ignored. In future study data from Islamic banks may explore these variables more effectively. Furthermore, as all the independent variables are having significant relationship with the selection of the mortgage provider, so new explanatory variables may be added to increase the reliability of the model. 


\section{References}

Anderson, W. T., Cox, E. P. \& Fulcher, D. G. (1976), Bank selection decision and marketing segmentation. Journal of marketing, 40(1), 40-45.

Aldlagain, A. \& Buttle, F. (2001). Consumer involvement in financial services. International journal of bank marketing, 19(6), 232-245.

Asabere, P. K. \& Hoffman, F. E. (1997). Discount Point Concessions and the Value of Homes with Conventional versus Nonconventional Mortgage Financing. Journal of Real Estate Finance and Economics, 15(3), 261-270.

Akamavi, R. K. (2005). Re-engineering service quality process mapping: e-banking process. International Journal of Bank Marketing, 23(1), 28-53.

Boyd, W., Myron L. \& White, C. (1994). Customers' preferences for the financial services. An international journal of bank marketing, 12, 9-16.

Buist, H., Mae, F., Avenue, W., \& Yang, T.T. (1998). Pricing the Competing Risks of Mort gage Default and Pre payment in Stochastic Metropolitan Economies. Managerial finance, 24 (9/10).

Charlier, E. \& Bussel, A. V. (2003). Prepayment Behavior of Dutch Mortgagors: An Empirical Analysis. Real Estate economics, 31(2), 165-204.

Coates, D. (2008). The Irish sub-prime residential mortgage sector: international lessons for an emerging market. J Hous and the Built Environ, 23, 131-144.

Cummings, C. (2008). A practitioner's guide to mortgage regulation. Journal of Financial Regulation and Compliance, 16(1), 93-107.

Calem, R. S. \& Follain, J. R. (2007). Regulatory Capital Arbitrage and the Potential Competitive Impact of Basel II in the Market for Residential Mortgages. J Real Estate Finan Econ, 35, 197-219.

Devlin, J. F. (2002). Analysis choice criteria in the home loan market. The international journal of the bank marketing, 20, 212-227.

Edris, T. A. (1997). Services considered important to business customer and determinants of bank selection in Kuwait. International journal of the bank marketing, 15(4), 126-133.

Fayman, A. \& He, L.T. (2011). Prepayment risk and bank performance. The Journal of Risk Finance, 12(1), 2640.

Farquhar, J. D., Panther, T. \& Wright, L. T. (2008).To have and to hold: managing channels in UK high street financial services. Qualitative Market Research: An International Journal, 11(4), 425-438.

Gait, A. \& Worthington, A. (2008). An empirical survey of individual consumer, business firm and financial institution attitudes towards Islamic methods of finance. International Journal of Social Economics, $35(11)$.

Heijes, G. (2008). Culture, convenience or efficiency Customer behavior in choosing local or foreign banks in China. Chinese Management Studies, 2(3), 183-202.

Hung, C. (1999). An Anomaly in the Pricing of Bank Non-Interest Mortgage Charges. Journal of Economics and Finance, 23(2), 162-169.

Johnson, L. D. \& Neave, E. H. (2008). The subprime mortgage market: familiar lessons in a new context. Management Research News, 31(1), 12-26.

Khazeh, K. \& Decker, W. (1992). How customers chose banks. Journal of retail banking, 14(4), 41- 44.

Kotykhov, M. (2005). Determinant Attributes of Customer Choice of Banks Supplying Mortgage Products, Thesis, 143-144.

Leece, D. (1997). Mortgage design in the 1990s: theoretical and empirical issues. Journal of Property Finance, $8(3), 226-245$.

Liu, J. G. \& Xu, E. (1998). Pricing of Mortgage- Backed Securities with Option- Adjusted Spread. Managerial Finance, $24(9 / 10)$.

Lymperopoulos, C., Chaniotakis, I. E. \& Soureli, M. (2006).The importance of service quality in bank selection for mortgage loans. Managing Service Quality, 16(4), 365-379

Mori, M., Diaz, J. \& Ziobrowski, A. J. (2010). The Journal of Behavioral Finance, 11, 82-91.

Moutinho, L. \& Smith, A. (2000). Modeling bank customer satisfaction through mediation of attitudes towards human and automated banking. International Journal of Bank Marketing, 18(3), 124-134.

Meidan, A. \& Chin, A. C. (1995). Mortgage-pricing determinants: a comparative investigation of national, regional and local building societies. International Journal of Bank Marketing, 13(3), 3-11. 
O'Loughlin, D., Szmigin, I. \& Turnbull, P. (2004). From relationships to experiences in retail financial services. The International Journal of Bank Marketing, (7), 522-539.

Patrício, L., Fisk, R. P. \& Cunha, J. F. (2003). Improving satisfaction with bank service offerings: measuring the contribution of each delivery channel. Managing Service Quality, 13(6), 471-482.

Roos, I., Gustafsson, A. \& Edvardsson, B. (2006). Defining relationship quality for customer-driven business development a housing-mortgage company case. International Journal of Service Industry Management, 17(2), 207-223.

Scanlon, K. Lunde, J. \& Whitehead, E. (2008). Mortgage Product Innovation in Advanced Economies: More Choice, More Risk1. European Journal of Housing Policy, 8(2), 109-131.

Schuck, E. J. (1994). Financial Risk Sharing in New Zealand's Residential Mortgage Market. Journal of Property Finance, 5(1), 41-50.

Sharma, D. (2010).Transferring home price risk to investors from individual borrowers. The Journal of Risk Finance, 11(4), 416-423.

Talaga, J. \& Buch, J. (1998). Customer trade-offs among mortgage instrument variables. International journal of bank marketing, 16(6), 264-270.

Ta, H. P. \& Har, K. Y. (2000). A study of bank selection in Singapore using the analytical hierarchy process. International journal of bank marketing, 18(4), 170-180.

Ulengin, B. (1998). Using the hierarchical information integration to examine customer's preferences in banking. International journal of bank marketing, 16, 202-209.

Zineldin, M. (1996). Bank strategic positioning and some determinants of bank selection. International Journal of Bank Marketing, 14(6), 12-22.

Zineldin, M. (2005). Research And Concepts Quality and customer relationship management (CRM) as competitive strategy in the Swedish banking industry. The TQM Magazine, 17(4), 329-344. 